\title{
Pengaruh Umur dan Jenis Kelamin Itik Alabio Terhadap Nilai Energi Metabolis dan Retensi Nitrogen Bungkil Maggot Hermetia illucens
}

\author{
A. Gunawan, M. S. Djaya, R. Samudera \\ Universitas Islam Kalimantan Muhammad Arsyad Al Banjari, Banjarmasin 70123
}

\begin{abstract}
ABSTRAK
Bungkil maggot black soldier fly (Hermetia illucens) merupakan hasil ekstraksi dari tepung maggot, sehingga kandungan lemak dari bungkil maggot lebih rendah dari tepung maggot. Kualitas protein dan kandungan energi metabolis bungkil maggot belum diketahui, padahal penting untuk formulasi pakan unggas. Oleh karena itu penelitian ini bertujuan untuk mengetahui nilai energi metabolis semu yang dikoreksi dengan nitrogen $\left(\mathrm{AME}_{\mathrm{n}}\right)$ dan retensi nitrogen bungkil maggot yang dicobakan pada itik jantan dan betina pada berbagai umur. Penelitian menggunakan 32 ekor itik alabio yang ditempatkan pada kandang individual. Rancangan yang digunakan adalah rancangan acak kelompok dengan empat perlakuan dan empat ulangan. Perlakuan yang dicobakan terdiri dari P1: umur itik 4 minggu, P2: umur itik 8 minggu, P3: umur itik 12 minggu, dan P4: umur itik 24 minggu. Data yang diperoleh dianalisis varian dan uji wilayah berganda Duncan. Hasil penelitian menunjukkan bahwa umur itik berpengaruh terhadap nilai energi metabolis dan retensi nitrogen bungkil maggot, sedangkan jenis kelamin tidak berpengaruh nyata $(\mathrm{P}>0,05)$ terhadap nilai $\mathrm{AME}_{n}$ dan retensi nitrogen bungkil maggot. Kesimpulan dari penelitian ini bahwa kandungan energi metabolis dan retensi nitrogen bungkil maggot pada itik umur 8-24 minggu relatif sama, sedangkan pada umur itik 4 minggu kandungan energi metabolis dan retensi nitrogen lebih rendah daripada umur itik 8-24 minggu.
\end{abstract}

Kata kunci: Bungkil maggot black soldier fly, Energi metabolis, Retensi nitrogen, Umur, Jenis kelamin itik

\section{The Influence of Age and Sex Alabio Duck on Metabolizable Energy and Nitrogen Retention Content of Maggot Extracted Hermetia Illucens}

\begin{abstract}
Maggot black soldier fly extracted (Hermetia illucens) were mechanical extracted from maggot meal, so that the fat content of the maggot extracted is lower than the maggot meal. Quality protein and metabolizable energy content maggot extracted is not yet known, but important for poultry feed formulations. Therefore, this study aims to determine the value of apparent metabolizable energy corrected for nitrogen $\left(A M E_{n}\right)$ and nitrogen retention maggot extracted is experimentedat male and female duck at various ages of duck. The study used 32 Alabio duck placed in individual cages. The design used was randomized block design with four treatments and four replications. Data obtained were analyzed variance and Duncan's multiple range test. The treatments experimented consisted of P1: the ducks age of 4 weeks, P2: the ducks age of 8 weeks, P3: the ducks age of 12 weeks, and P4: the ducks age of 24 weeks. The results of this research showed that the age of ducks effect the value of metabolizable energy and nitrogen retention maggot extracted, whereas sex are not significant effect $(P>0.05)$. It can be concluded thatthe content of metabolizable energy and nitrogen retention maggot extracted at 8-24 weeks of age ducks are relatively similar, while at the age of 4 weeks ducks metabolizable energy content and nitrogen retention lower than the ducks age of 8-24 weeks.
\end{abstract}

Keywords: Black soldier fly maggot extract, Metabolizable energy, nitrogen retention, Duck old

\section{PENDAHULUAN}

Keberhasilan usaha peternakan selain ditopang oleh penguasaan manajemen beternak dan pengadaan bibit yang baik, juga harus diimbangi dengan penyediaan ransum yang berkualitas dengan harga yang relatif murah. Biaya untuk ransum pada usaha peternakan unggas dapat mencapai lebih dari $70 \%$ dari total biaya produksi, dan porsi terbesar digunakan untuk mensuplay kebutuhan energi metabolis (Donohue dan Cunningham, 2009). Untuk mengurangi biaya pakan perlu dicari pakan alternatif yang bisa dihasilkan dari limbah industri pertanian (bungkilintisawit/ palm kernel meal).

Cara baru untuk mendapatkan sumber bahan pakan yang berkualitas adalah melalui proses

*Penulis Korespondensi: Aam Gunawan

Alamat: J1. Adhyaksa No.2 Kayu Tangi, Banjarmasin 70123

E-mail: aamgunawan@yahoo.com biokonversi dengan memanfaatkan bungkil inti sawit (BIS)sebagai media tumbuh maggot black soldier fly (BSF). Bungkil inti sawit dapat dijadikan media yang baik untuk pertumbuhan maggot, karena di dalam BIS terdapat substrat kaya nutrien yang sangat istimewa untuk perkembangan maggot. Begitu telur lalat menetas, maggot segera makan nutrien yang terdapat di dalam BIS sehingga terjadi proses biokonversi BIS menjadi biomassa maggot (Olivier, 2009).

Beberapa hasil penelitian menunjukkan bahwa maggot layak digunakan sebagai alternatif sumber pakan untuk unggas (Despines dan Axtell, 1995). Zuidhof et al. (2003) menyatakan bahwa larva lalat rumah yang ditumbuhkan di media dedak gandum mengandung apparent metabolizable energy (AME) $17,9 \mathrm{MJ} / \mathrm{kg}$ dan protein kasar $593 \mathrm{~g} / \mathrm{kg}$ (dry matter), dengan kandungan asam amino yang lebih tinggi dari tepung kedelai kecuali asam amino arginin sedikit lebih rendah. 
Kandungan lemak yang tinggi pada tepung maggot BSF yaitu berkisar 22-33\% (Gunawan, 2012) dapat mengurangi konsumsi ransum, sehingga tepung maggot perlu diturunkan kadar lemaknya dengan cara ekstraksi agar diperoleh bahan pakan baru dengan nama bungkil maggot. Rintangan penggunaan bungkil maggot BSF sebagai bahan pakan unggas adalah belum diketahuinya kandungan energi terutama energi metabolis yang berguna untuk penyusunan ransum unggas, dan bagaimana kualitas proteinnya yang ditunjukkan dengan nilai retensi nitrogen. Oleh karena itu penelitian ini bertujuan untuk mengetahui kandungan energi metabolis bungkil maggot pada berbagai umur itik dan nilai retensi nitrogennya.

\section{MATERI DAN METODE}

\section{Materi}

1. Bungkil maggot

Bungkil maggot yang digunakan sebanyak 2 $\mathrm{kg}$, diperoleh dari hasil ekstraksi mekanis tepung maggot.

2. Ternak Percobaan

Penelitian ini menggunakan itik jantan dan betina masing-masing sebanyak 16 ekor dengan umur berbeda dan dibagi secara acak ke dalam 32 unit kandang cages. Masing-masing kandang diisi dengan satu ekor itik.

\section{Kandang dan Perlengkapan}

Kandang yang digunakan dalam penelitian adalah kandang individu dengan ukuran 45 x 45 x $25 \mathrm{~cm}$. Alas kandang terbuat dari kawat ram ukuran $1 \mathrm{~cm}$ untuk memudahkan penampungan ekskreta itik, dan di bagian bawah kawat ram disediakan baki penampung ekskreta. Tempat air minum ukuran satu liter diisi separuhnya dan diletakan di dalam kandang.

\section{Alat}

1. Timbangan digital merek sigma kapasitas $100 \mathrm{~g}$ dengan tingkat ketelitian $0,01 \mathrm{~g}$, digunakan untuk menimbang bungkil maggot dan ekskreta.

2. Spuit berukuran $10 \mathrm{ml}$, digunakan sebagai alat untuk melakukan force feeding.

3. Mangkuk plastik, digunakan sebagai tempat untuk mencampurkan bungkil maggot dengan air hingga berbentuk pasta.

4. Blender, digunakan untuk menghaluskan maggot hingga berbentuk tepung

5. Alat ekstraksi, digunakan untuk menghasilkan bungkil maggot

6. Peralatan untuk analisis kandungan protein dan energi bruto.

\section{Rancangan Percobaan dan Analisis Statistik}

Penelitian dilakukan secara eksperimental di Laboratorium Ternak Unggas. Penelitian menggunakan dua macam perlakuan yaitu jenis kelamin dan umur. Jenis kelamin berperan sebagai kelompok yang terdiri dari dua level yaitu jantan dan betina, sedangkan umur berperan sebagai perlakuan yang terdiri dari empat level secara terperinci keempat perlakuan tersebut adalah:

P1 : Umur itikAlabio 4minggu

P2 : Umur itik Alabio 8 minggu

P3 : Umur itik Alabio 12 minggu

P4 : Umur itikAlabio 24minggu

Rancangan yang digunakan dalam penelitian ini adalah rancangan acak kelompok (RAK) dengan empat anak contoh. Adapun model matematiknya adalah:

$$
Y i j=\mu+\alpha i+\beta j+\varepsilon i j+\varepsilon i j k
$$

\section{Keterangan:}

Yij $=$ respon hasil perlakuan ke i pada ulangan ke $\mathrm{j}$

$\mu \quad=$ nilai tengah umum

$\alpha \mathrm{i}=$ pengaruh perlakuan pada taraf ke $\mathrm{i}$

$\beta \mathrm{j} \quad=$ pengaruh kelompok pada taraf ke $\mathrm{j}$

eij $=$ pengaruh komponen galat

eijk = pengaruh galat anak contoh

Asumsi:

1. Nilai eij menyebar normal dan bebas satu sama lain

2. Nilai harapan dari $\varepsilon i j=0$

3. Ragam dari $\varepsilon i j=\delta^{2}$

4. Pengaruh perlakuan bersifat tetap

Jika berdasarkan hasil analisis ragam terdapat pengaruh yang signifikan, maka pengujian dilanjutkan dengan menggunakan uji wilayah berganda Duncan (Steel and Torrie,1982).

\section{Prosedur Penelitian}

1. Pembuatan bungkil maggot

Maggot yang sudah kering diblender sehingga terbentuk tepung maggot. Tepung maggot selanjutnya diekstrak dengan cara dipanaskan pada suhu $110^{\circ} \mathrm{C}$ dan dipres untuk mengeluarkan minyaknya, sehingga dihasilkan bungkil maggot BSF.

2. Analisis Kandungan Nutrien

Bungkil maggot dianalisis kandungan air, nitrogen dan energi brutonya.

3. Pengukuran Energi Metabolis dan Retensi Nitrogen

Pengukuran energi metabolis mengacu pada prosedur yang dilakukan oleh Sibbald (1976a) dan Sibbald (1976b). Itik dikandangkan pada kandang sangkar tunggal (individual cage) diberi air minum dengan cukup dan dipuasakan selama 24 jam. Bungkil maggot sebanyak 20-50 g dicampur dengan air 10-25 $\mathrm{ml}$ atau sampai berbentuk pasta. Dimasukkan ke dalam spuit berukuran latau $10 \mathrm{ml}$, selanjutnya secara paksa (force feeding) dimasukkan lewat esophagus dan jumlah bungkil maggot yang berhasil masuk ke dalam esophagus dicatat. Itik dikembalikan pada kandangnya 
dan baki penampung ekskreta dipasang. Ekskreta yang tertampung disemprot dengan asam borat 5\% setiap 3 jam untuk menghindari penguapan nitrogen. Penampungan ekskreta dilakukan selama 24 jam. Ekskreta yang berhasil ditampung dibersihkan dari bulu dan kotoran lainnya, kemudian ditimbang dan selanjutnya dikeringkan. Ekskreta yang sudah kering dihaluskan untuk dianalisis kandungan nitrogen dan energi brutonya.

\section{Pengukuran Variabel Respon}

1. Energi metabolis $(\mathrm{kkal} / \mathrm{kg})$, dihitung berdasarkan persamaan yang dikemukakan oleh Zarei (2006) yaitu:

$$
A M E_{n}=\frac{\left(F_{i} \times G E_{f}\right)-\left(E \times G E_{e}\right)-(N R \times K)}{F_{i}}
$$

Keterangan:

$\mathrm{AME}_{\mathrm{n}}$ : Energi metabolis semu yang dikoreksi dengan retensi nitrogen (kkal/g)

$\mathrm{F}_{\mathrm{i}} \quad$ : Banyaknya pakan yang dikonsumsi (g)

E : Jumlah ekskreta (g)

$\mathrm{GE}_{\mathrm{f}} \quad$ : Energi bruto pakan $(\mathrm{kkal} / \mathrm{g})$

$\mathrm{GE}_{\mathrm{e}} \quad$ : Energi bruto ekskreta $(\mathrm{kkal} / \mathrm{g})$

NR : Retensi nitrogen $(g) N R=\left(F_{i} \times N_{f}\right)-$ $\left(\mathrm{E} \times \mathrm{N}_{\mathrm{e}}\right)$

$\mathrm{K} \quad$ : Konstanta koreksi untuk nilai energi nitrogen yang diretensi $(8,73 \mathrm{kkal} / \mathrm{g}$ untuk setiap gram nitrogen)

2. Retensi nitrogen (\%),berdasarkan pada rumus yang dikemukakan oleh Zarei (2006), maka persentase nitrogen yang diretensi dapat dihitung dengan menggunakan rumus:

$$
N R(\%)=\left[\frac{\left(F_{i} \times N_{f}\right)-\left(E \times N_{e}\right)}{\left(F_{i} \times N_{f}\right)}\right] X 100 \%
$$

$\begin{array}{lll}\text { Keterangan: } & \\ \mathrm{NR} & : & \text { Retensi nitrogen (\%) } \\ \mathrm{N}_{\mathrm{f}} & : & \text { Nitrogen pakan }(\%) \\ \mathrm{N}_{\mathrm{e}} & : & \text { Nitrogen ekskreta }(\%) \\ \mathrm{F}_{\mathrm{i}} & : & \text { Pakan yang dikonsumsi (g) } \\ \mathrm{E} & : & \text { Jumlah ekskreta }(\mathrm{g})\end{array}$

\section{HASIL DAN PEMBAHASAN}

\section{Energi Metabolis}

Perhitungan kandungan energi metabolis dalam penelitian ini berdasarkan kandungan bahan kering (BK) $100 \%$, sehingga tidak dapat langsung digunakan untuk penyusunan ransum ternak unggas yang umumnya berdasarkan asfed. Dengan demikian perlu dikonversi dulu dari bahan kering ke asfed sebelum digunakan untuk penyusunan ransum unggas. Rata-rata kandungan energi metabolis bungkil maggot pada berbagai umur itik alabio jantan dan betina disajikan pada Tabel 1.

Rata-rata kandungan energi metabolis bungkil maggot yang dicobakan pada itik jantan sebesar $2.967,27 \mathrm{kkal} / \mathrm{kg}$ lebih rendah dari yang dicobakan pada itik betina sebesar 3.143,91 kkal/kg (Tabel 1). Selanjutnya rata-rata kandungan energi metabolis bungkil maggot yang dicobakan pada berbagai umur itik, nilai tertinggi diperoleh pada perlakuan umur itik 8 minggu yaitu sebesar $3.235,59 \mathrm{kkal} / \mathrm{kg}$, kemudian diikuti oleh perlakuan umur itik 12 minggu (3.167,76 $\mathrm{kkal} / \mathrm{kg}$ ) lalu umur itik 24 minggu $(3.037,51 \mathrm{kkal} / \mathrm{kg}$ ) dan terendah pada perlakuan umur itik 4 minggu sebesar $2.781,51 \mathrm{kkal} / \mathrm{kg}$. Bila dilihat dari kandungan energi brutonya bungkil maggot rata-rata mempunyai kadar energi bruto sebesar 4.614,75 kkal/kg (Gunawan et al., 2016). Nilai konversi dari energi bruto ke energi metabolis berturut-turut untuk umur itik 4, 8, 12, dan 24 minggu, adalah sebesar 60,$27 ; 70,11 ; 68,64$ dan $65,82 \%$.

Hasil analisis ragam terhadap data kandungan energi metabolis menunjukkan bahwa perlakuan jenis kelamin tidak berpengaruh $(\mathrm{P}>0,05)$ terhadap kandungan $\mathrm{AME}_{\mathrm{n}}$ bungkil maggot, artinya bahwa kandungan $\mathrm{AME}_{\mathrm{n}}$ bungkil maggot relatif sama pada itik jantan atau itik betina.Hasil penelitian ini sama dengan penelitian yang dilakukan oleh Iskandar et al. (2001) pada ayam silangan pelung dengan kampung, bahwa jenis kelamin ayam tidak mempengaruhi besarnya energi ransum yang diretensi. Umur itik berpengaruh terhadap kandungan $\mathrm{AME}_{\mathrm{n}}$ dari bungkil maggot. Hal ini membuktikan bahwa umur itik yang berbeda, mempunyai kemampuan yang bebeda dalam mencerna bungkil maggot. Lopez dan Leeson (2008) menyatakan bahwa nilai apparent metabolizable energy (AME) terbukti bervariasi menurut umur ayam yang digunakan dalam percobaan terutama untuk soybean meal (SBM).

Tabel 1. Rata-rata kandungan energi metabolis (kkal/kg) bungkil maggot pada umur dan jenis kelamin itik yang berbeda

\begin{tabular}{cccc}
\hline \hline \multirow{2}{*}{ Umur Itik (Minggu) } & \multicolumn{2}{c}{ Jenis Kelamin } & \multirow{2}{*}{ Rataan } \\
\cline { 2 - 3 } & Jantan & Betina & $2.781,51^{\mathrm{b}}$ \\
8 & $2.556,51$ & $3.006,52$ & $3.235,59^{\mathrm{a}}$ \\
12 & $3.247,24$ & $3.223,94$ & $3.167,76^{\mathrm{a}}$ \\
24 & $3.006,26$ & $3.329,26$ & $3.037,51^{\mathrm{a}}$ \\
\hline Rataan & $3.053,08$ & $3.015,94$ & \\
\hline a,b Ang & $2.967,27$ & $3.143,91$ &
\end{tabular}

\footnotetext{
${ }^{\mathrm{a}, \mathrm{b}}$ Angka yang diikuti dengan huruf superskrip yang berbeda ke arah kolom menunjukkan perbedaan yang nyata $(\mathrm{P}<0,05)$
} 
Tabel 2. Rata-rata retensi nitrogen (\%) bungkil maggot pada umur dan jenis kelamin itik yang berbeda

\begin{tabular}{cccc}
\hline \hline \multirow{2}{*}{ Umur Itik (Minggu) } & \multicolumn{2}{c}{ Jenis Kelamin } & \multirow{2}{*}{ Rataan } \\
\cline { 2 - 3 } & Jantan & Betina & $83,96^{\mathrm{b}}$ \\
8 & 81,26 & 86,66 & $91,90^{\mathrm{a}}$ \\
12 & 91,59 & 92,22 & $91,27^{\mathrm{a}}$ \\
24 & 90,09 & 92,46 & $90,09^{\mathrm{a}}$ \\
\hline Rataan & 90,70 & 89,50 & \\
\hline $\mathrm{a}, \mathrm{b}$ Angka vang diikuti dengan huruf suberskrip vang berbeda ke arah kolom menuniukkan perbedaan vang nvata (P<0.05)
\end{tabular}

Kandungan energi metabolis yang tinggi pada perlakuan umur itik 8-24 minggu, disebabkan nilai retensi nitrogen pada umur tersebut juga tinggi (Tabel 2). Dale dan Fuller (1984) menyatakan bahwa retensi nitrogen mempunyai pengaruh yang lebih besar terhadap AME bahan pakan seperti bungkil kedelai karena akumulasi protein yang lebih tinggi.

Kandungan energi metabolis semu tepung maggot yang dicobakan pada puyuh menurut Gunawan et al. (2012) berkisar $3028-3373 \mathrm{kkal} / \mathrm{kg}$, sedangkan kandungan energi metabolis bungkil maggot yang diperoleh dari hasil penelitian ini pada umur itik 4-24 minggu berkisar 2.556,51-3.329,26 kkal/kg bahan kering. Dengan demikian kandungan energi metabolis tepung maggot dan bungkil maggot hampir mendekati kandungan energi metabolis tepung ikan menhaden $2.820 \mathrm{kkal} / \mathrm{kg}$ (dasar asfed 92\% bahan kering) (NRC, 1994) atau bila dihitung ke dasar bahan kering menjadi $3.065 \mathrm{kkal} / \mathrm{kg}$.

\section{Retensi Nitrogen}

Retensi nitrogen merupakan salah satumetode untuk menilai kualitas protein bahan pakan dengan mengukur konsumsi nitrogen dan pengeluaran nitrogen dalam ekskreta, sehingga dapat diketahui jumlah nitrogen yang tertinggal atau diretensi di dalam tubuh. Komposisi nutrien bungkil maggot yang digunakan dalam penelitian ini mengandung protein kasar 48,40\%, serat kasar $0,80 \%$, lemak kasar $22,82 \%$, BETN 18,29\%, kalsium $0,94 \%$ dan fosfor $0,31 \%$.Rata-rata retensi nitrogen yang diperoleh dalam penelitian disajikan pada Tabel 2.

Rata-rata retensi nitrogen bungkil maggot yang dicobakan pada itik jantan sebesar $88,41 \%$ lebih rendah dari yang dicobakan pada itik betina sebesar 90,21\% (Tabel 2). Selanjutnya rata-rata retensi nitrogen bungkil maggot yang dicobakan pada berbagai umur itik, nilai retensi nitrogen tertinggi diperoleh pada perlakuan umur itik 8 minggu yaitu sebesar 91,90\%, kemudian diikuti oleh perlakuan umur itik 12 minggu $(91,27 \%)$ lalu umur itik 24 minggu (90,09\%) dan terendah pada perlakuan umur itik 4 minggu yaitu sebesar 83,96\%. Hasil analisis varian menunjukkan bahwa perlakuan jenis kelamin tidak berpengaruh $(\mathrm{P}>0,05)$ terhadap nilai retensi nitrogen, sedangkan perlakuan umur itik berpengaruh nyata $(\mathrm{P}<0,05)$ terhadap nilai retensi nirogen. Iskandar et al. (2001) melaporkan bahwa retensi nitrogen (dihitung berdasar nitrogen yang diretensi terhadap konsumsi nitrogen) pada ayam silangan pelung dengan kampung umur 4 atau 6 minggu tidak dipengaruhi oleh faktor perbedaan jenis kelamin. Umur itik 8-24 minggu memberikan nilai retensi nitrogen yang relatif sama, sedangkan pada umur itik 4 minggu menghasilkan nilai retensi nitrogen yang paling rendah dan berbeda nyata dengan ketiga umur itik lainnya. Tingginya nilai retensi nitrogen pada umur itik 8-24 minggu, menunjukkan bahwa pada umur tersebut proses pencernaan sangat baik, sehingga banyak nitrogen yang terserap dalam tubuh itik. Hasil penelitian ini sama dengan hasil penelitian yang dilakukan oleh Lopez dan Leeson (2007) nilai nitrogen retensi ransum yang diberikan pada broiler umur 7 hari lebih rendah dari umur 35 hari.

Bila dibandingkan dengan tepung maggot, bungkil maggot memberikan nilai retensi nitrogen yang lebih baik dari tepung maggot yang mempunyai nilai retensi nitrogen 63,96-75,84\% (Gunawan et al., 2012). Hal ini dikarenakan kandungan protein bungkil maggot lebih tinggi daripada tepung maggot. Sejalan dengan penelitian de Coca-Sinova et al. (2010) pada kedelai yang berkadar protein rendah dan tinggi. Hasil penelitiannya menunjukkan bahwa retensi nutrien termasuk retensi nitrogen umumnya lebih tinggi pada kedelai berprotein tinggi daripada tepung kedelai berprotein rendah.

Nilai retensi nitrogen yang diperoleh dalam penelitian ini tergolong tinggi, hal ini menunjukkan bahwa bungkil maggot memiliki kualitas protein yang baik, mengandung asam amino esensial dan non esensial yang lengkap dan seimbang, dan dapat dicerna dan diserap oleh saluran pencernaan itik jantan maupun itik betina. Nilai retensi nitrogen yang rendah menunjukkan kualitas protein dari bahan pakan tersebut rendah. Awoniyi et al. (2003) menyatakan bahwa makin tinggi level penggantian tepung ikan oleh tepung maggot menyebabkan nilai retensi nitrogen yang makin rendah, hal ini menunjukkan kualitas protein dari tepung maggot lebih rendah dari protein tepung ikan. Berbeda dengan hasil penelitian Adeniji (2007) bahwa dengan semakin meningkatnya level maggot dalam ransum, nilai retensi protein ransum tidak berbeda nyata berkisar dari $64,17-72,22 \%$.

\section{SIMPULAN}

Kandungan energi metabolis $\left(\mathrm{AME}_{\mathrm{n}}\right)$ bungkil maggot dan banyaknya nitrogen yang diretensipada itik jantan dan betina relatif sama. Kandungan energi metabolis dan retensi nitrogen bungkil maggot pada itik 
berumur 8-24 minggu lebih tinggi dari pada umur itik 4 minggu.

\section{UCAPAN TERIMA KASIH}

Penulis mengucapkan terima kasih kepada Direktorat Penelitian dan Pengabdian Kepada Masyarakat Direktorat Jenderal Pendidikan Tinggi Kemendikbud (DP2M Dikti) dan Ketua Umum Badan Pengurus Yayasan UNISKA MAB yang telah memberikan bantuan anggaran penelitian kepada penulis. Selanjutnya kepada Laboratorium Nutrisi dan Makanan Ternak Universitas Padjadjaran yang telah memberikan bantuan fasilitas untuk analisis kadar air, energi bruto dan kadar proteindari ekskreta itik dan bungkil maggot.

\section{DAFTAR PUSTAKA}

Adeniji, A. A. 2007. Effect of replacing groundnut cake with maggot meal in the diet of broilers. International Journal of Poultry Science 6(11): 822-825.

Awoniyi, T. A. M., V. A. Aletor and J. M. Aina. 2003. Performance of broiler- chickens feed on maggot meal in place of fish meal. International Journal of Poultry Science 2(4): 271-274.

Dale, N. and Fuller. 1984. Correlation of protein content of feedstuffs with the magnitude of nitrogen correction in true metabolizable energy determination. Poultry Science 63: 1008-1012.

de Coca-Sinova, A., E. Jimenez-Moreno, J. M. Gonzalez-Alvarado, M. Frikha, R. Lazaro, and G. G. Mateos. 2010. Influence of source of soybean meal and lysine content of the diet on performance and total tract apparent retention of nutrients in broilers from 1 to 36 days of age. Poultry Science 89: 1440-1450.

Despines, J. L. and Axtell, R. C. 1995. Feeding behavior and growth of broiler chicks fed larvae of darkling beetle alphitobius diaperinus. Poultry Science 74: 331-336.

Donohue, M. and D. L. Cunningham. 2009. Effects of grain and oilseed prices on the costs of US poultry production. The Journal of Applied Poultry Research 18: 325-337.

Gunawan, A. 2012. Aplikasi Maggot Black Soldier Fly (Hermetia illucens) yang Dibiakkan dalam Manur Unggas sebagai Campuran Pakan Periode Pertumbuhan dan Produksi Telur Puyuh (Coturnix coturnix japonica). Disertasi. Program Pascasarjana Universitas Padjadjaran Bandung.

Gunawan, A., N. Widaningsih dan M. S. Djaya. 2012. Nilai Energi Metabolis dan Retensi Nitrogen Maggot yang Berasal dari Berbagai Jenis Manur pada Burung Puyuh. Media Sains 4(2): 109-116.

Gunawan, A., N. A. Fauzana, M. S. Djaya, dan R. Samudera. 2016. Limbah Pabrik Minyak Sawit untuk Produksi Maggot Black Soldier Fly. Laporan Penelitian MP3EI.

Iskandar, S., P. Handayani, dan D. Sudrajat. 2001. Retensi Energi dan Nitrogen dan Laju Pencernaan pada Ayam Silangan Pelung X Kampung pada Pola Pemberian Ransum dengan Protein Berbeda. Seminar Nasional Teknologi Peternakan dan Veteriner. 597-605.

Lopez, G. and S. Leeson. 2007. Relevance of nitrogen correction for assessment of metabolizable energy with broiler to forty-nine days of age. Poultry Science 86: 1696-1704.

Lopez, G., and S. Leeson. 2008. Assessment of the nitrogen correction factor in evaluating metabolizable energy of corn and soybean meal in diets for broiler. Poultry Science 87: 298-306.

NRC. 1994. Nutrient Requirements of Poultry. Ninth Revised Edition. National Academy Press. Washington, D. C.

Olivier P. A. 2009. The On-site Recycling of Food Residuals. Available at: http://www.esrla.com/pdf/biocycle.pdf Accessed 1 May 2009.

Sibbald, I. R. 1976a. The effect of the duration of starvation of the assay bird on true metabolizable energy values. Poultry Science 55: 1578-1579.

Sibbald, I. R. 1976b. The true metabolizable energy values of several feedingstuffs measured with roosters, laying hens, turkeys and broiler hens. Poultry Science 55: 1459-1463.

Steel, R. G. D. and J. H. Torrie. 1982. Prinsip dan Prosedur Statistika: Suatu Pendekatan Biometrik. Edisi Kedua. Terjemahan Bambang Sumantri. Gramedia Pustaka Utama. Jakarta.

Zarei, A. 2006. Apparent and true metabolizable energy in artemia meal. International Journal of Poultry Science 5 (7): 627-628.

Zuidhof, M. J., C. L. Molnar, F. M. Morley, T. L. Wray, F. E. Robinson, B. A. Khan, L. Al-Ani, and L. A. Goonewardene. 2003. Nutritive value of house fly (mucca domestica) larvae as a fed supplement for turkey poults. Animal Feed Science and Technology 105: 225-230. 